\title{
GUBERNATORIAL INFLUENCE AND STATE BUREAUCRACY
}

\author{
F. TED HEBERT \\ JEFFREY L. BRUDNEY \\ University of Oklahoma \\ DEIL S. WRIGHT \\ University of North Carolina
}

\begin{abstract}
Previous research has concentrated on differences in gubernatorial power across states. Relatively little research attention has been devoted to the sources of gubernatorial influence over state agencies. Based on data collected from state administrators in 1978, this study examines the effects of four sets of factors on the perceived influence of the governor over the state administrative apparatus. These sets are: formal powers of the governor, characteristics of the agencies, characteristics of the positions held by administrators, and personal characteristics of these officials. Results show that these factors account for nearly one-fourth of the variance in the influence of the governor over state agencies, as reported by agency heads.
\end{abstract}

Undoubtedly, the governor is at last becoming an officer worthy of the name.

Leslie Lipson, The American Governor from Figurehead to Leader (1939)

Within the last fifteen years, there has been a virtual explosion of reform in state government. In most of the states, as a result, the governor is now truly the master of his own house, not just the father figure.

Larry Sabato, Goodbye to Good-Time Charlie (1978)

\footnotetext{
Authors' Note: This is a revised version of a paper prepared for presentation at the 1981 Annual Meeting of the American Political Science Association, New York, September 26, 1981. The authors gratefully acknowledge the support of the Earhart Foundation to conduct portions of this research and thank Robert E. England for assistance in data analysis.
} 
Students of the American state governorship have been appalled at the weakness of the institution, but at the same time they have been hopeful that implementation of appropriate reforms will produce officials able to fill the important role the title seems to describe. Although written almost forty years apart, the epigraphs above reflect the views of two such investigators. Even the titles of their books exhibit the combined dissatisfaction with the past and hope for the future. Both Lipson and Sabato conclude that the American political system has placed responsibilities on the governors that exceed either the capacities of individual incumbents or the institutional strengths of the offices themselves.

Beginning with Lipson's (1939) work, students of the state governorship have examined the offices to determine the nature and extent of formal authority provided the incumbents, a task aided by the existence of fifty states across which comparisons can be made. Based on both impressionistic and quantitative measures of gubernatorial power, these investigations chiefly concerned variation in the power of the governor across states. While this approach has produced a substantial literature (for example, Dometrius, 1979; Sabato, 1978; Ransone, 1966; Schlesinger, 1971, 1965; Lipson, 1939), relatively little attention has been devoted to differences in gubernatorial power over individual executive agencies.

Taking the individual agency as its focus, the present analysis of gubernatorial power concentrates on the state administrator side of the relationship. Although little precedent exists for such an approach in studies of the states, several recent works have adopted this perspective at the federal level. For example, Kaufman (1981) writes extensively about the environmental elements confronting federal administrators. He treats the "execuive branch set," including the president, as but one of many sources of influence over bureau chiefs. He finds that heads of agencies perceive their organizations as having lives of their own, even apart from the departments in which they formally function (Kaufman, 1981: 57). Like Redford (1969), Kaufman sees as unattainable the traditional hierarchical model of administrative agencies, with the chief executive exercising unilateral 
control. The influence of Congress and other environmental actors is too strong to allow such an arrangement (Kaufman, 1981: 181).

Despite near consensus on the lack of monolithic presidential influence over federal administrators (for example, see Browne, 1980; Rourke, 1976; Mosher, 1968), much of the literature regarding the governorship implicitly assumes that a hierarchical structure is operative or can be created with respect to state bureaucracy. However, like their federal counterparts, some state administrators may be closely circumscribed by the control of the chief executive, while others may elude it, even in the same state. This inquiry focuses on variation in the power of the governor across state agencies, examining the factors that condition gubernatorial control.

\section{THE SCHLESINGER INDEX AND GUBERNATORIAL POWER}

A study by Beyle (1978) finds that governors report spending more time on "managing state government" $(27 \%)$ than on any other task. ${ }^{1}$ According to governors themselves, then, a major aspect of gubernatorial leadership is the exercise of influence over the administrative agencies in the state.

Perhaps the most important step taken in this area of research was the introduction of an index of formal powers of the governor, devised by Schlesinger (1965). Schlesinger's index is based on four of the institutional features of the state governorship that earlier scholars had applied in nonquantitative assessments: the powers of the governor to serve more than one term in office, to control the budget of the state, to veto legislation, and to appoint individuals to positions of authority in state government.

A number of investigators have used the original Schlesinger (1965) index or a slightly modified version (Schlesinger, 1971) in order to assess gubernatorial power in studies of state policymaking (for example, Fry and Winters, 1970; Dye, 1969; Sharkansky, 1968; Wright, 1967). However, the index has received sub- 
stantial criticism for several reasons. First of all, the index does not assign varying weights to its constituent components, nor was it validated against an external criterion (Dometrius, 1979). Moreover, the index does not recognize variation in the importance of the offices over which the governor exercises appointive power (Ransone, 1966: 351). Because the index is based solely on the formal powers of the governor, it is insensitive to differences in informal power. Most important for present purposes, the Schlesinger index is a state-level measure intended for crossstate comparison; hence, it does not tap variation in gubernatorial power across agencies.

Noting some of these problems, Dometrius (1979) developed a revised version of the Schlesinger index. Dometrius weighted the components of the index according to their relationships with a criterion measure culled from the American State Administrators Project (ASAP), a series of surveys of senior administrators heading various departments in state governments. The criterion solicits the relative judgment of these officials regarding whether the "governor or the legislature exercises greater control and oversight over your agency." Dometrius shows that his revised index is correlated more highly with this criterion than is the Schlesinger index.

At the conclusion of his article, Dometrius observes that the index of gubernatorial power he proposes has a practical advantage over measures based directly on surveys of state administrators. Of course, the primary advantage is that survey data are not continuously available, and, in fact, successful frequent repetitions of an elite survey of the kind represented by the American State Administrators Project would be very difficult. In contrast, a measure based on formal gubernatorial powers can be recalculated each year or even more frequently as the policies of states change.

However, it is possible to query state administrators periodically to determine their perceptions of gubernatorial power. When this is done, it is most appropriate to use measures of gubernatorial power emanating from these data. The Dometrius measure is limited (as was Schlesinger's) by its inability both to assess in- 
teragency variations and to encompass the informal powers wielded by the governor, such as media exposure, prestige of the office, and influence over the electoral party. Governors may have accumulated a stock of political IOUs during previous service in the state; moreover, they most likely do not choose - nor are they able - to exercise the same level of influence over all agencies in the state. When available, it seems appropriate to draw on measures sensitive to these aspects of gubernatorial power.

Consequently, this research draws on data from the most recent American State Administrators Survey, conducted in 1978. A questionnaire was mailed to the heads of 76 types of agencies in the 50 states, with the names and addresses of respondents provided by the Council of State Governments. A total of 1393 agency heads participated in the survey.

The 1978 ASAP data allow examination of gubernatorial influence in ways precluded by the traditional measures of gubernatorial power. Our fundamental task is to explain variation in the influence of governors across state agencies. Rather than using states as the units of analysis (as one must with the traditional measures), we use individual administrators. What factors in the work environments or personal experiences of state administrators account for differences in gubernatorial influence? Phrased in this fashion, our basic research question permits us to employ the traditional power measure as one of the independent variables. Dometrius's work leads us to expect that formal power may account for a portion of the variance. But, since we are interested in variation across agencies, regardless of state, we expect other variables to contribute as well.

\section{METHODOLOGY}

\section{MEASURING GUBERNATORIAL INFLUENCE}

This focus on explaining gubernatorial influence at the level of individual state agencies requires a change in approach to 
measurement. While the legislature-governor comparison item employed by Dometrius to validate his index of formal powers represents a step in the direction we move, the 1978 American State Administrators Survey includes several other measures of gubernatorial influence that avoid the relative, and perhaps zerosum, connotation of this criterion. These questions solicit a "freestanding" or "self-anchoring" assessment of the influence of the governor in four key areas of agency operations. On a four-point scale ranging from "none" to "high," state administrators rated the degree of influence exercised by the governor over decisions made by their agencies with regard to total budget, budgets for specific programs, major changes in agency policy, and agency rules and regulations.

While each of these areas might constitute a significant dependent variable in itself, the focus of this article is on the overall influence of the governor over an agency. Table 1 shows that administrators' perceptions of gubernatorial influence across the four areas are highly intercorrelated: According to these respondents, the governor tends to exert comparable influence across the four agency decision areas. Accordingly, the ratings of the administrators were summed across the items to yield a single index of gubernatorial influence over the agency. The index is correlated highly with the criterion measure employed by Dometrius $(r=.47)$ as well as with other indicators of gubernatorial influence, including the extent to which respondents viewed the governor as offering new ideas to improve agency programs and operations $(r=.41)$, taking policy initiatives leading to shifts in agency priorities $(r=.30)$, and introducing legislation affecting the agency $(\mathrm{r}=.25)$. The index serves as the dependent variable in subsequent analysis.

Although this index does not explicitly encompass all aspects of the informal power of the governor, it does capture variation in the level of gubernatorial influence across state agencies. The utility of the index lies in the fact that it is constructed from the assessments of knowledgeable actors - the heads of various state agencies - of the degree of influence exercised by the governor in four specific areas of agency operations. In order to distinguish 
TABLE 1

Intercorrelations of Gubernatorial Influence Items ${ }^{a}$

\begin{tabular}{|c|c|c|c|c|c|}
\hline $\begin{array}{l}\text { Total agency } \\
\text { budget level }\end{array}$ & 1.00 & & & & \\
\hline $\begin{array}{l}\text { Budgets for } \\
\text { specific } \\
\text { agency } \\
\text { programs }\end{array}$ & $.69 *$ & 1.00 & & & \\
\hline $\begin{array}{l}\text { Major agency } \\
\text { policy } \\
\text { changes }\end{array}$ & .53 & .58 & 1.00 & & \\
\hline $\begin{array}{l}\text { Agency rules } \\
\text { and regula- } \\
\text { tions }\end{array}$ & .39 & .45 & .60 & 1.00 & \\
\hline $\begin{array}{l}\text { Additive index } \\
\text { of gubernatorial } \\
\text { power }\end{array}$ & .78 & .83 & .85 & .79 & 1.00 \\
\hline & $\begin{array}{c}\text { Total } \\
\text { budget } \\
\text { level }\end{array}$ & $\begin{array}{l}\text { Budgets } \\
\text { for } \\
\text { specific } \\
\text { programs }\end{array}$ & $\begin{array}{l}\text { Major } \\
\text { policy } \\
\text { changes }\end{array}$ & $\begin{array}{l}\text { Rules } \\
\text { and } \\
\text { regula- } \\
\text { tions }\end{array}$ & $\begin{array}{c}\text { Index of } \\
\text { guberna- } \\
\text { torial } \\
\text { power }\end{array}$ \\
\hline
\end{tabular}

a. N ranges from 1295 to 1347 .

*All Pearson product-moment correlations statistically significant minimally at .0001 level.

this measure from the indexes constructed by Schlesinger, Dometrius, and others - and because we think the label more appropriate -we use the expression "perceived gubernatorial influence" as opposed to "gubernatorial power." The expression represents the degree of influence operative in state agencies according to their directors.

\section{UNITS OF ANALYSIS: STATES VERSUS AGENCIES}

Given the persuasiveness of Schlesinger's work as well as the relative ease of measuring and comparing the formal powers of the governor across states, the bulk of research examining gubernatorial power has taken the state as the unit of analysis. As enlightening as this research has been, it has yielded negligible information regarding the determinants of gubernatorial influence at the agency level. 
Two consequences follow from the shift in emphasis in the present study to individual agencies as the units of investigation. First, the nature and size of the sample available for empirical analysis changes from the 50 states to the objects of influence attempts by governors - the 1393 state administrative agencies represented in the 1978 American State Administrators Project. Because these data were obtained from individual agency heads, the number of factors affecting gubernatorial influence, and hence the amount of variation to be accounted for, is far greater than at the highly aggregated state level. Thus the task of explanation is considerably more difficult; one cannot expect to replicate the magnitude of associations found in analyses based on the states.

Second, it may be unrealistic to treat all state agencies - from libraries to human services - as equal units of analysis. In his critique of Schlesinger's index, for example, Ransone (1966) notes that governors are not likely to evaluate all state agencies as equally important; governors may attempt to wield greater influence over agencies they consider significant (Weinberg, 1977). This hypothesis suggests that major state agencies may fall under stronger gubernatorial influence than do others. In order to examine this possibility, the analysis below is first conducted for all agencies for which data are available, and subsequently for those agencies considered "major." Of course, the meaning of this term must remain somewhat subjective. In the present study, this judgment is based primarily on the ranking of agencies with respect to personnel and budget. ${ }^{2}$ These criteria yielded 18 major agencies across the states: higher education, welfare, employment security, social services, transportation, highways, mass transit, mental health, health, corrections, education, vocational education, medicaid, mental retardation, juvenile delinquency, law enforcement, budget, and administration and finance.

\section{EXPLAINING GUBERNATORIAL INFLUENCE}

Four general types of factors may account for the assessments of state agency heads of the degree of influence exercised by the 
governor over their agencies. These factors are: the formal powers of the governor; characteristics of the various agencies; characteristics of the positions held by state administrators; and personal characteristics of these officials. ${ }^{3}$ The effect of each set of factors is examined in turn.

\section{FORMAL POWERS}

The discussion of the Schlesinger and Dometrius indexes above is not intended to suggest that the formal powers of the governor are of no importance in the explanation of influence. In fact, variation in these powers across states may contribute to differences in perceived influence, even when measured at the agency level, for they set the boundaries within which governors wield influence. However, because several variables intervene between the formal powers of the governor and the actual exercise of influence (for example, interest in particular policy arenas, evaluation of chances of success in influence attempts, and the like), the relationship between the two is probably not great.

This expectation is borne out empirically. Table 2 summarizes the results of analyses examining the relationship between the four sets of explanatory factors and the index of perceived gubernatorial influence developed from the 1978 ASAP data. The table shows that the correlation between the Dometrius index of formal powers of the governor and the assessments of agency heads of gubernatorial influence over their agencies is only $r=.14$. Thus, while not devoid of importance, formal powers (as Dometrius measured them) do not account for a substantial portion of the variation in perceived influence. ${ }^{4}$ Apparently, administrators do not respond simply to such fixtures of state constitutions as the governor's power to veto legislation or to serve multiple terms in office. Other variables must also affect the influence governors have over state agencies.

\section{AGENCY CHARACTERISTICS}

One possible source of variation that may help to account for differences in perceived gubernatorial influence is the nature of 
TABLE 2

Pearson Correlations Between Gubernatorial Influence and Formal Powers, Agency Characteristics, Job Characteristics, and Personal Characteristics ${ }^{a}$

Independent Variables

Formal Powers of the Governor

Dometrius Index (1978)

Agency Characteristics

Non-staff/staff

Reorganization impact

Percent of budget from earmarked funds

Percent of budget from federal funds

Federal agency contact

$.09 *$

Federal fund impact

Job Characteristics

Appointment process

Non-merit based/merit based

Immediate superior

Time on policy development

Personal Characteristics

$\begin{array}{lc}\text { Race (non-Black/Black) } & .05 \\ \text { Sex } & .04 \\ \text { Highest degree held } & -.03 \\ \text { Years in present position } & -.13 \star \\ \text { Professionalism } & -.03 \\ \text { Governor's campaign participation } & .04\end{array}$

a. Correlations based on $\mathrm{N}=780$ cases for which data were available on all variables.

*Denotes relationship statistically significant minimally at .05 level.

the agencies themselves. In fact, the literature includes several suggestions to guide the formulation of hypotheses.

Throughout the twentieth century, periodic reform efforts placed considerable emphasis on creation of appropriate staff support for chief executives. Budget offices, planning offices, and departments of administration are examples. If governors were to be held accountable, they should have available the staff resources to pursue assigned tasks. Further, these staff agencies should have a special relationship with the chief executive, holding 
responsibility for assisting in carrying out (and seeing that others carry out) the chief executive's program.

While the exact links between these agencies and the chief executive have varied (even the federal budget office was from 1921 to 1939 in the Department of the Treasury - an organizational step removed from the president), it is reasonable to expect that these agencies would come under greater gubernatorial influence. As Table 2 shows, this hypopthesis gains support: Administrators of staff agencies reported greater gubernatorial influence over their agencies' affairs than did heads of nonstaff agencies $(r=.18) .^{5}$

A second agency characteristic related significantly to administrators' perceptions of gubernatorial influence pertains to the impact of government reorganization on state agencies. In the last decade a wave of major structural reorganization efforts swept across the states, with 21 states undergoing such executive branch changes between 1965 and 1977 (Nicholson, 1978). More than twothirds of the agency heads sampled reported that administrative reorganizations had been undertaken in their states. In fact, $54 \%$ said that their own agencies had been affected.

The administrators were asked whether the most recent state reorganization had decreased, left unchanged, or increased the control of the governor over their agencies. Heads of agencies reporting increased gubernatorial control more often cited higher levels of gubernatorial influence $(\mathrm{r}=.13)$. This finding is not trivial, for the emphasis is on the effects of a change in control: Administrators who recall a reorganization that strengthened the governor in relation to the agency are more likely to find a higher level of present gubernatorial influence. This suggests that the reorganization process itself may be a tool of gubernatorial influence and that the efforts of reform movements to strengthen governors have not been wasted.

The remaining four agency characteristics concern sources of funds. Students of budgeting have long been concerned that earmarking of revenues removes control of spending and programs from budget offices and, hence, in most states, from the governor (Burkhead, 1956: 282). In this analysis, therefore, it was ex- 
pected that administrators reporting larger percentages of their budgets coming from earmarked revenues would report lower gubernatorial influence. However, this hypothesis does not receive support in the 1978 ASAP data: Table 2 reveals no significant relationship between perceived influence and receipt of earmarked funds. Governors apparently have available means to exercise influence over agencies sufficient to offset any control lost due to earmarking.

The second variable pertaining to agency funding is the receipt of federal monies. In a 1977 report, the Advisory Commission on Intergovernmental Relations reported that in the past, "governors were frustrated and 'bypassed,' since many federal programs were operating outside their executive control" (ACIR, 1977: 216). Yet, this relationship may no longer hold, for during the 1960s and 1970s the states implemented changes to relieve this frustration, particularly the A-95 process requiring central clearance of many agency grant applications. A review of these changes suggests that they have been at least partially successful (ACIR, 1977). To the extent that this is the case, the governor may have become a "chief federal systems officer" with special ability to manage programs initiated and financed by the federal government (Wright, 1982: 271). Thus agency heads whose budgets depend heavily on federal funds may find the governor especially influential in the affairs of the agency. Table 2 offers a modicum of support for this hypothesis, for, although it is not strong, a positive relationship links agency receipt of federal funds to a perception of gubernatorial influence.

The superior political position of the governors as well as the administrative and review powers now granted them may assist agencies receiving federal funds in coping with the sometimes adverse environment in which these monies are disbursed. According to these data, federal aid is frequently dispensed in an environment at least somewhat unfavorable to the agency. For example, $68 \%$ of the agency heads receiving federal aid reported that they would allocate these funds differently were federal "strings" not attached to them; $30 \%$ said that their reallocation would be "substantially" or "radically" different. In addition, two- 
thirds of these administrators agreed that the receipt of federal aid seems uncertain, making revenue estimation difficult. The opportunity to alleviate such problems in the receipt of federal funds offers the governor an importrant avenue for exerting influence over the agency. Some governors, as seen by aid-recipient agency heads, take advantage of the opportunity.

In order to assess this relationship, these two items (allocation of funds and uncertainty of funds) were combined to form an index of "federal fund impact." The index is scored so that the more adverse the circumstances surrounding the receipt of federal aid by an agency (that is, allocation not satisfactory, funds uncertain), the higher the (adverse) impact. A second item counting the number of federal agencies supplying funds to a state agency provided a rough indicator of the complexity of its aid environment ("federal agency contact"). Both variables are thought to be related positively to administrators' perceptions of gubernatorial influence. In fact, Table 2 shows that agency heads who must rely on several sources of funding and who are faced with an "adverse" impact of federal aid report that the governor has greater influence over the affairs of their agency than do other administrators.

\section{JOB CHARACTERISTICS}

Another possible source of gubernatorial influence lies in the characteristics of the positions held by the individuals to be influenced. For example, both the Schlesinger index and the Dometrius index of formal powers include a quantity representing the appointive authority of the governor throughout state government. At the level of individual agencies, the critical variable is the extent of involvement of the governor in the appointment of an agency head. This variable is scored so that the highest quantity indicates gubernatorial appointment without the need for approval by the state legislature, and the opposite extreme indicates choice by popular election. ${ }^{6}$ The method of appointment yielded the highest zero-order correlation with gubernatorial influence $(\mathrm{r}=.38)$. As anticipated, the greater the involvement of the gover- 
nor in the appointment of an agency head, the greater the governor's reported influence over the agency.

A second prime opportunity for gubernatorial influence occurs when the governor is the immediate superior of an agency head. While the superior may correspond closely to the individual(s) responsible for the appointment of the agency head, the correspondence is not perfect $(\mathrm{r}=.60)$. It seems reasonable to expect that if an administrator reports directly to the governor, he or she will be more easily subject to the governor's influence. The results reported in Table 2 support this hypothesis $(r=.38)$.

These variables describing appointment method and the administrator's immediate superior are far more important in their impact on gubernatorial influence than is the status of the agency head under a merit system. The protection offered by a merit system might be expected to lead to independence from such influence. Surprisingly, administrators not covered by a merit system were no more likely to report high levels of gubernatorial influence than were agency heads who are covered $(r=.03)$.

Finally, among the job characteristic variables is one that represents a quality that is especially difficult to measure. Agency heads perform a variety of functions and tasks, depending partly on their own predilections and partly on the role expectations of those with whom they work and from whom they take directives. As a measure of the nature of their job activities, administrators indicated the percentage of time they spent on three major responsibilities: policy development, internal management, and public support. It was hypothesized that agency heads who are more deeply involved in policy development (as opposed to these other activities) would be under stronger gubernatorial influence since the governor, as chief executive, has particular policy responsibility. As Table 2 shows, the expected positive relationship is found $(\mathrm{r}=.12)$.

\section{PERSONAL CHARACTERISTICS}

The final set of variables examined includes a number that are of intrinsic interest because of the role they play in lay considera- 
tions of public employee "quality." Such considerations, including participation in campaigns for elective offices, frequently suggest that the personal backgrounds of individuals will influence their policy positions and job performance. However, despite the early hope that social background qualities would provide important explanatory variables in systematic studies of decision making, the effort has most often failed or resulted in quite weak relationships. $^{7}$

Findings here are consistent with these earlier results. Only one of the relationships represented by correlation coefficients in this segment of Table 2 attains statistical significance, and it concerns a variable marking ongoing experience - the number of years the administrator has held the directorship position. Other personal variables, such as race, sex, education, professionalism (measured by the holding of licenses and conference participation), and participation in the governor's election campaign seem to have little impact on administrators' perceptions of gubernatorial influence.

Although these results confirm our expectation that personal characteristics would show only weak relationships, it is important to emphasize the apparent impact of tenure. Heclo (1977) uses the expression "government of strangers" in reference to the upper levels of federal administration. Rapid turnover results in an inability to become fully acquainted with one's colleagues or one's job. But Kaufman (1981: 133), in discussing federal bureau chiefs, notes the ability of persons with long tenure to transcend limits imposed on others. Prominent examples include J. Edgar Hoover and Admiral Hyman Rickover. Apparently, tenure may have the same effect at the state level, for administrators who have held their positions longer report reduced levels of gubernatorial influence. Perhaps familiarity with the job and with other sources of support make such independence possible.

\section{MULTIVARIATE ANALYSIS}

To estimate the combined impact on perceived gubernatorial influence of the four sets of explanatory factors (formal powers, 
TABLE 3

Hierarchical Regression of Determinants of Gubernatorial Influence: All Agencies ${ }^{\mathrm{a}}$

\begin{tabular}{|c|c|c|c|c|c|}
\hline & Variables by Block & $\mathrm{r}$ & Beta ${ }^{b}$ & $\begin{array}{l}\text { Cumulative } \\
\mathrm{R} / \mathrm{R}^{2}\end{array}$ & $\begin{array}{l}\text { Addition to } R^{2} \\
\text { for Each Block }\end{array}$ \\
\hline \multicolumn{2}{|c|}{ Block 1: Formal Powers } & & & $.14 / .02^{\mathrm{c}}$ & .02 \\
\hline & Dometrius Index (1978) & .14 & $.10 *$ & & \\
\hline \multicolumn{6}{|c|}{ Block 2: Agency } \\
\hline & Characteristics & & & $.31 / .10$ & .08 \\
\hline & Non-staff/staff & .19 & $.14 *$ & & \\
\hline & Reorganization impact & .13 & $.06 \star$ & & \\
\hline & Percent of budget from & & & & \\
\hline & rederal funds & .07 & -.01 & & \\
\hline & Federal fund impact & .09 & $.02 \pi$ & & \\
\hline \multirow[t]{5}{*}{ Block } & 3: Job Characteristics & & & $.49 / .24$ & .14 \\
\hline & Appointment process & .38 & $.20 *$ & & \\
\hline & Immediate superior & .38 & $.21 *$ & & \\
\hline & Time on policy & & & & \\
\hline & development & .12 & $.07 *$ & & \\
\hline \multicolumn{6}{|c|}{ Block 4: Personal Character- } \\
\hline & istics & & & $.49 / .24$ & .001 \\
\hline & $\begin{array}{l}\text { Years in present } \\
\text { position }\end{array}$ & -.13 & -.03 & & \\
\hline
\end{tabular}

a. $\mathrm{N}=780$ cases for which data were available on all variables.

b. Standardized regression coefficient for final equation.

c. All $\mathrm{R} / \mathrm{R}^{2}$ statistically significant minimally at .0001 level.

*Denotes relationship statistically significant minimally at .05 level.

agency characteristics, job characteristics, and personal characteristics), each variable attaining statistical significance in its relationship presented in Table 2 was examined in a multiple regression analysis. Each set of factors was entered in hierarchical fashion into the regression equation; the results are presented in Table 3. The Dometrius index of formal powers was the first variable included, and as noted above, it yields a correlation of .14 with perceptions of gubernatorial influence, thus explaining $2 \%$ of the variance. 
The inclusion of the agency characteristics in the regression equation increases the multiple correlation coefficient $(\mathrm{R})$ to .31 . At this point, $10 \%$ of the variation in perceived influence has been explained. However, the effects of two of the funding variables percentage of agency budget received from federal sources and contact with federal agencies cannot be substantiated at the .05 level of statistical significance. Nevertheless, the index assessing the impact of federal funds remains significantly associated with the perceived influence of the governor.

The three job characteristics of agency heads, the manner of their appointment, immediate superior, and time spent on policy development, maintain significant relationships with the criterion. This set of variables increases the multiple correlation to .49 , thus accounting for $24 \%$ of the variation. The change in these statistics with the addition of the single personal characteristic (years in present position) is negligible (visible only in the third decimal place), and the effect of this variable is not statistically significant. In sum, then, the four sets of factors explain approximately one-fourth of the variation in the influence of the governor over state administrative agencies as reported by their directors.

\section{MAJOR AGENCIES AND GUBERNATORIAL INFLUENCE}

Governors may attempt to exercise greater influence over agencies they consider significant or major. Although the 1978 ASAP data do not include these assessments of the governors, agencies can be classified as "major" according to other criteria, such as size of budget and number of personnel, as described above. ${ }^{8}$ Based on this categorization, the data provide some support for the hypothesis. On the 12-point scale of gubernatorial influence, directors of major agencies perceived the governors as somewhat more influential (mean $=9.75$, standard deviation $=2.16$ ) than did heads of agencies not considered major (mean $=9.13$, standard deviation $=3.00$ ). The difference in means is .62 , statistically significant at the .001 level. 
TABLE 4

Hierarchical Regression of Determinants of Gubernatorial Influence: Major Agenciesa

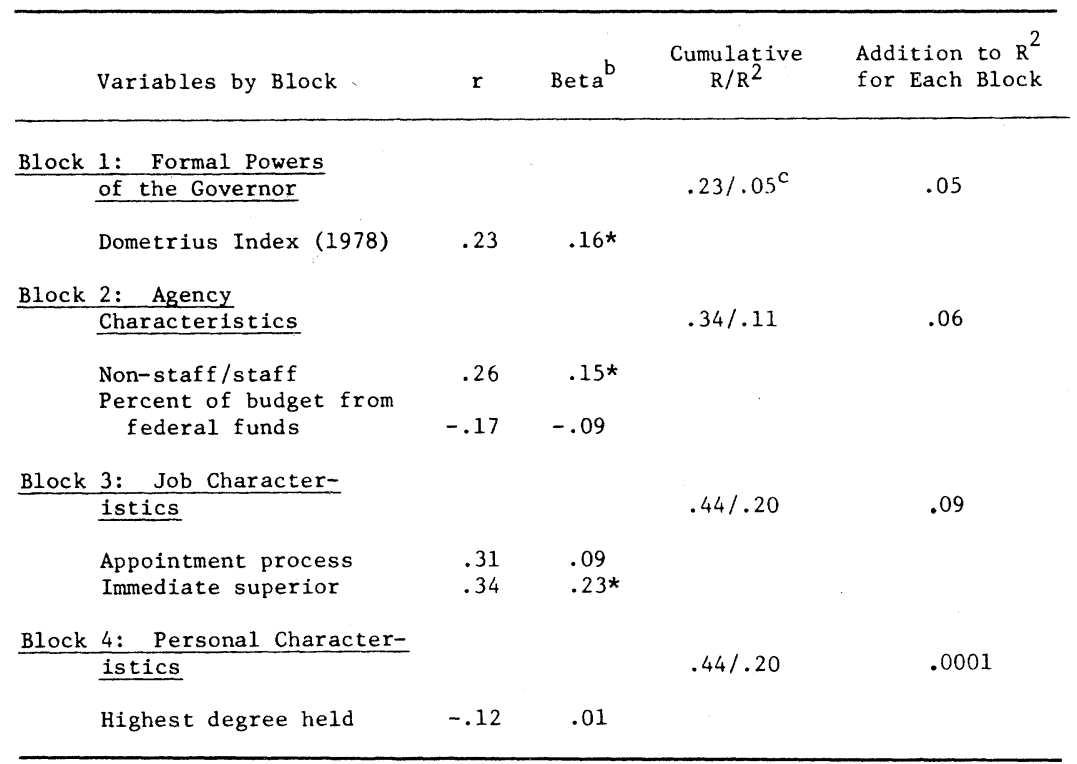

a. $\mathrm{N}=216$ cases for which data were avaiable on all variables.

b. Standarized regression coefficient for final equation.

c. All $\mathrm{R} / \mathrm{R}^{2}$ statistically significant minimally at .0001 level.

*Denotes relationship statistically significant minimally at .05 level.

Although this increment is not substantial, it does suggest that governors may treat major agencies in a fashion different from others. The finding also raises the possibility that the variables explaining administrators' perceptions of gubernatorial influence over major agencies may not be identical to those applicable to all agencies. The limited span of gubernatorial attention and control and the rather large number of agencies demanding oversight - an average number of 85 agencies per state (Fox, 1974: 14)-may force concentration on the major agency subset (Weinberg, 1977). To test for differences, the analysis was replicated upon this group of major agencies.

This step produced few surprises. Table 4 displays the results of the hierarchical regression analysis for major agencies, includ- 
ing only those variables attaining statistical significance $(\mathrm{p}=.05)$ at the zero-order level. The table indicates that although the number of variables related to perceived gubernatorial influence is reduced for major agencies, the variables that demonstrate strongest relationships for all agencies remain significant. In addition, the proportion of variation explained is attenuated only slightly, from $24 \%$ to $20 \%$.

For major agencies, the effect of the governor's formal powers (Dometrius index) is enhanced, accounting for $5 \%$ of the variation in perceptions of gubernatorial influence. Two agency characteristics - type (nonstaff versus staff) and percentage of agency budget from federal funds - contribute an additional $6 \%$ to explained variation. Contrary to expectation, however, the receipt of federal monies is related negatively to the influence of the governor, intimating that despite reforms in the agency funding process (ACIR, 1977), federal funds may impede gubernatorial control, at least for major agencies. Among the job characteristics, both the appointment method by which agency heads achieve office and the immediate superior to whom they report demonstrate positive relationships with perceived gubernatorial influence, together adding $9 \%$ to explained variation.

Finally, the single personal characteristic of agency heads significant at the zero-order level for all agencies, years in present position, is replaced in this analysis of major agencies by the administrator's level of formal education: Agency heads with less education report higher levels of influence by the governor. However, this relationship virtually disappears in the multivariate analysis so that, as was the case for all agencies, the contribution of personal characteristics to the explanation of perceived gubernatorial influence is negligible.

\section{CONCLUSION}

The foundations of gubernatorial influence over administrative agencies extend beyond the formal powers of the governor. Dif- 
ferences in formal powers, as commonly measured, are able to account for little of the variation in reported influence. The study by Dometrius (1979) showed formal power differences as considerably more important in explaining variation across states. The apparent disagreement can be attributed to the fact that Dometrius employed a different measure of perceived influence and aggregated data within states. The latter procedure, especially, accentuated the magnitude of relationship. While this step was warranted for Dometrius's purpose of improving upon the Schlesinger measure of gubernatorial power, it is not appropriate in the present context of attempting to explain variation in perceptions of gubernatorial influence across state agencies. At this level, the contribution of formal powers of the governor is modest and needs to be supplemented by other factors.

Two additional categories of variables contribute significantly to the explanation of gubernatorial influence: characteristics of state agencies and of the positions held by agency heads. Included among these variables were the method by which the administrator was appointed and the identification of the administrator's superior. While these may be seen as indicative of formal gubernatorial powers, it must be noted that, as measured, they are specific to particular administrators rather than representative of the generalized power measured by Schlesinger and Dometrius. Like the measure of formal gubernatorial power, the personal characteristics of agency heads add little explanatory power. The four sets of factors can account for nearly one-fourth of the variation in the influence of the governor as perceived by the full sample of state agency heads, and slightly less (one-fifth) among the subsample of directors of major agencies. The results of the analyses based on these two groups were quite similar.

Although this represents an important beginning in the study of gubernatorial influence over state agencies, substantial variance remains to be explained. Perhaps one reason that variables included do not explain a larger proportion of the variance is that they fail to reflect the full complexity of agency environment. Kaufman's (1981) study of federal bureaus is suggestive of this complexity, as is Schlesinger's (1971: 211-220) reference to "indeterminant government" - the general notion that no one is in charge. State agencies have opportunities to respond to a 
variety of influence sources, ranging from formal institutions (legislatures, courts, and so on) to interest and clientele groups. Perhaps the influence a governor can exercise over state agencies is conditioned by the relative influence of these other sources. Further study of these influence sources may yield a more complete picture of the ability-and the limitations - of the governor to manage state government.

\section{NOTES}

1. This statistic is based on responses of governors from sixteen states, each of whom estimated the percentage of time spent on nine activities. These estimates were averaged to provide the percentages reported by Beyle (1978).

2. To identify major agencies, all agency types were ranked according to mean number of personnel and mean budget, as reported by responding agency heads. The top fifteen types on each list were considered for inclusion. On this basis, sixteen types were selected. Because this list included no staff agencies, two-also considered major - were added: budget office and office of administration and finance.

3. The theoretical justification for selecting variables from these categories is presented below as the variables are introduced into the analysis.

4. The correlation between the Schlesinger index of formal powers and the index of gubernatorial influence developed from the 1978 ASAP data is nearly identical, $\mathrm{r}=.12$.

5. The agencies classified as "staff" are: administration and finance, budget, taxation (overall administration), centralized accounting, preaudit, federal-state relations (Washington office), information systems, personnel, planning, and purchasing.

6. Intermediate categories include appointment by: governor with legislative consent or by board with governor's consent; department head; civil service or merit system procedure; and board without governor's consent or by legislature.

7. Matthews (1954) indicates the need to search for links between such personal characteristics and decisions made by public officials.

8. See note 2 .

\section{REFERENCES}

Advisory Commission on Intergovernmental Relations ACIR (1977) Improving Federal Grants Management. Washington DC: Author.

BEYLE, T. L. (1978) "The governor and the public." State Government 51 (Summer): 180-186.

BROWNE, W. P. (1980) Politics, Programs, and Bureaucrats. Port Washington, NY: Kennikat.

BURKHEAD, J. (1956) Government Budgeting. New York: John Wiley.

DOMETRIUS, N. C. (1979) “Measuring gubernatorial power.” J. of Politics 41 (May): 598-610.

DYE, T. (1969) "Executive power and public policy in the states." Western Political Q. 27 (December): 926-939. 
FOX, D. M. (1974) The Politics of City and State Bureaucracy. Pacific Palisades, CA: Goodyear.

FRY, B. J. and R. F. WINTERS (1970) “The politics of redistribution.” Amer. Pol. Sci. Rev. 64 (June): 508-522.

HECLO, H. (1977) A Government of Strangers. Washington, DC: Brookings.

KAUFMAN, H. (1981) The Administrative Behavior of Federal Bureau Chiefs. Washington, DC: Brookings.

LIPSON, L. (1939) The American State Governor from Figurehead to Leader. Chicago: Univ. of Chicago Press.

MATTHEWS, D. R. (1954) The Social Background of Political Decision-Makers. Garden City, NY: Doubleday.

MOSHER, F. C. (1968) Democracy and the Public Service. New York: Oxford Univ. Press.

NICHOLSON, J. (1978) "State administrative organization activities, 1976-77," pp. 105-115 in Book of the States. Lexington, KY: Council of State Governments.

RANSONE, C. B., Jr. (1966) "Scholarly revolt in dullsville: new approaches to the study of state government." Public Administration Rev. 26 (December): 343-352.

REDFORD, E. S. (1969) Democracy in the Administrative State. New York: Oxford Univ. Press.

ROURKE, F. E. (1976) Bureaucracy, Politics, and Public Policy. Boston: Little, Brown. SABATO, L. (1978) Goodbye to Good-Time Charlie. Lexington, MA: D. C. Heath.

SCHLESINGER, J. A. (1971) "The politics of the executive," in H. Jacob and K. N. Vines (eds.) Politics in the American States. Boston: Little, Brown.

- - (1965) "The politics of the executive," in H. Jacob and K. N. Vines (eds.) Politics in the American States. Boston: Little, Brown.

SHARKANSKY, I. (1968) "Agency requests, gubernatorial support and budget success in state legislatures." Amer. Pol. Sci. Rev. 62 (December): 1220-1231.

WEINBERG, M. W. (1977) Managing the State. Cambridge: MIT Press.

WRIGHT, D. S. (1982) Understanding Intergovernmental Relations. Monterey, CA: Brooks/Cole.

_ - (1967) "Executive leadership in state administration." Midwest Pol. Sci. Rev. 11 (February): 1-26.

F. Ted Hebert is Professor of Political Science at the University of Oklahoma, with major teaching and research interests in public administration and intergovernmental relations.

Jeffrey L. Brudney is an Assistant Professor of Political Science at the University of Oklahoma. His fields of primary interest are public administration, urban politics, and research methodology.

Deil S. Wright is Professor of Political Science and Research Professor, Institute for Research in Social Sciences, at the University of North Carolina, Chapel Hill. His principal interests are in federalism and intergovernmental relations, and public administration. 